\title{
Informal Trade as a Predominant Factor in the Local Economy of Ambato, Ecuador
}

\author{
William Fabián Teneda Llerena \\ Technical University of Ambato \\ Edwin Santamaría-Freire \\ Technical University of Ambato \\ María Dolores Guamán Guevara \\ Technical University of Ambato
}

This study identifies the effect of informal or unregulated commerce on the local economy of the city of Ambato, Ecuador. Trade has social and economic repercussions; the population participating in trade is made up of people facing unemployment, economic crisis and lack of opportunities. Informal sellers seek to earn income for their families; in the process, they may work outside of regulations or ordinances that affect formal trade. The objective is to identify how the presence of informal merchants has affected the sales of formal traders in the city's markets, and whether the increase in the number of informal merchants has caused a reduction in formal sales. Both qualitative and quantitative research methods were to analyze economic data and socioeconomic factors. The sample is made up of 326 respondents to a questionnaire. The results show that the increase in informal commerce is due to the economic crisis, and that those who engage in this activity damage public spaces. The results determine that informal trade directly affects the local economy and suggests the creation of an advertising and promotion plan for formal trade will help mitigate the problem.

\section{SUMMARY}

This study sought to determine the effect of informal trade on traders in formal markets and on the local economy of Ambato, Ecuador. The social and economic impact on the prevalence of informal trade is notable; the market is comprised of people who face unemployment, the economic crisis and lack of opportunity and so choose this extralegal form of work. The aim of this study was to survey formal traders to identify how the presence of informal traders has affected the number of sales of perishable products in the city of Ambato. This was driven by the question of whether the number of informal traders causes a reduction in the formal sales of these products in the study area. A qualitative and quantitative data analysis approach examining economic figures and socioeconomic factors is used. The surveyed sample comprises 326 formal traders. The results of a questionnaire show that the observed increase in informal trade is largely due to the economic crisis, that those who are involved in this activity 
damage public spaces. The creation of an advertising and promotion plan is perceived as an option to help mitigate the problems informal trade causes.

\section{INTRODUCTION}

Political and social factors play a major role in the growth of a country's economy. These factors include the customs, values and beliefs common to the society (Pelfren \& Vlerick,2010). Parts of Latin America have resisted the adoption of modern forms of life and acceptance of some norms and regulations; within some communities, this has caused residents to seek income through extralegal means, including informal or unregulated trade. To improve the situation, the underlying issues, such as high unemployment, that lead residents to resort to seek income through extralegal means must be addressed (Minsky, 2013).

According to the methodology of the ENEMDU survey (INEC, 2014), and as described by Rivadeneira (2015), the formal sector is composed of those who work in establishments with more than 10 workers and those who work in establishments of up to 10 workers that have a single taxpayer registry (RUC), and maintain full accounting records. In another definition, the informal sector is regarded as a group of production units which, according to the definitions and classifications of the United Nations system of national accounts (UN, 2014), are part of the household sector, i.e. companies that belong to households and are not constituted in society.

These are two different ways, albeit linked, of considering and defining the informal sector: considering companies in relation to the legal and administrative regime and to define the informal sector as made up of companies that, in one way or another, do not conform to that regime. Or, considering the informal sector as a particular form of production and defining it in terms of the method of organization of the enterprise and the exercise of its activities (Organization for development and Economic Cooperation, 2008).

The informal economy is understood to include economic activities that largely occur out of the realm of official regulation, either because regulations do not apply or through a combination of weak enforcement and evasion (Sinha \& Kanbur, 2012). It is well known that the economic activities of the unregulated informal economy that generate income are a real or prominent presence in the day-to-day life of many people in the developing world (Lundval \& Johnson, 2006).

Thus, many researchers have begun to study the informal economy in developed countries. The results indicate that participation in non-formal activities is widespread, is not more typical of the poor, does not contribute greatly to average family income - but helps many poor families in difficult economic times - and is performed for both economic and non-economic reasons, including a lack of formal jobs (Jensen \& Findeis, 2010).

The term "informal economy" is broad and vague and can include domestic work in and around the house, carried out without cash payments by both family and non-family members, as well as criminal or "gray" activities in the workplace and elsewhere (Pahl, 2010). Such employment is characterized by dynamic family enterprises and self-employment and non-wage contributions to income strategies. The limited training of the "working class" is dedicated to the manufacturing industry (Mingione, 1995).

Informal trade is a social problem in all countries where it is practiced (Torres, 2015), carrying a series of consequences that directly or indirectly affect the local economy. A total of 2.7 million people work in the informal trade sector in Ecuador, according to the latest report of the National Institute of Statistics and Censuses (INEC). (,2015 leaders).

It has been determined that informal trade is a consequence of several factors present in a globalized environment (Scott, 2009) that, combined, have generated and, over the years, increased participation in such activities. A March report from INEC (2018) indicates that, in relation to the national employment rate, $45 \%$ of employed people are involved in the informal sector of the economy.

The unemployment rate is the percentage of people who would like to work but do not have a job (Mankiw, 2009). There are different types of unemployment, including frictional, structural and cyclical, 
all based on the economy of the country. The presence of cyclical unemployment is notable in Ecuador, increasing during recession and decreasing during expansion (Esquivel \& Muñoz, 2007).

An increase in the unemployment rate has been the main factor leading to an increase in informal work (Holzer, 1997). In this context, informal work does not only mean mobile selling of products, but also certain other businesses, such as informal taxis, and others that do not file taxes and are not subjected to governmental or regulatory oversight. Thus, informal traders are only a portion of this group of informal workers.

Data from the International Labour Organization (ILO) show that the percentage of total urban employment in Latin America grew from 50 percent in 1990 to 58 percent in 1997. This growth was attributed to growth of the informal economy, changes in the workforce due to demographic factors, especially among woman, and to significant migration from rural to urban environments (OrIT, 2002).

At the national level, in March 2015, legal employment represents 43.7\% of the EAP, a decrease of 1.8 percentage points with respect to the $45.5 \%$ reported for March 2014. The national inadequate employment rate is $52.1 \%$ in March 2015, compared to $49.4 \%$ for 2014, representing an annual increase of 2.65 percentage points. Finally, the national unemployment rate in March 2015 is 3.8\%, compared to $4.9 \%$ for 2014 . The reduction in unemployment and increase in inadequate employment are statistically significant at a $95 \%$ confidence level

With reference to the cities relevant to this study-Quito, Guayaquil, Cuenca, Machala and Ambato - the unemployment rate has statistically significant variation only in Guayaquil, where it falls 2.35 percentage points with respect to March 2014.(Rivadeneira, 2015). According to data from INEC for March 2015, Ambato's unemployment rate is $6.4 \%$, making it the city with the highest unemployment rate in the country.

It appears migration is one of the main causes driving these informal activities. Census data for 2001 indicate that Tungurahua was the province with the largest number of migrants in region 3, with 14,588 people $(43.5 \%)$ of residents having moved there from rural areas, representing $3.3 \%$ of the provincial population and $1.2 \%$ of the regional population. Tungurahua also contributed with $3.9 \%$ of the compatriots who left rural areas in 2001. According to the Central Bank of Ecuador, in 2006 Tungurahua was second place Region 3 in remittances (after Chimborazo), reporting 103 million dollars (Ministry of Production Coordination, 2011).

According to a September 2012 report from INEC, the total number of immigrants, i.e. people who left their province of origin, Tungurahua to move to other provinces, leaving the province, was 3463 people 2000 and 2010 (Vera, 2012).

The incidence of poverty in Tungurahua is $36 \%$ (equivalent to the national average), which is the lowest incidence within region 3 , which has an average poverty rate of $48 \%$. This means that $36 \%$ of the provincial population is under the poverty line-in other words, has per-capita income lower than the minimum cost of a basket of goods and services that would allow the satisfaction of basic needs (Ministry of Coordination of production, Employment and Competitiveness 2011). A major factor contributing to poverty and a corresponding increase in informal trade has been the limited creation of new jobs.

Through 2007, businesses generating jobs have included:

- Home accessories: 34 companies created; 471 workstations generated.

- Export agriculture: 2841 companies created, jobs 106074 generated.

- Energy: 8 companies created, 502 jobs generated.

- Metalworking: 40 companies created, 522 workstations generated.

- Tourism: 564 companies created, 5218 workstations generated.

Clothing, footwear and leather goods: 595 companies created, 6514 workstations generated. (Ministry of Production Coordination, 2011)

Although in the past the president of Ecuador has suggested that informal trade would be respected by constitutional order, there are now multiple controls that seek to curtail this type of work (Correa, 2013). This is in spite of the perspective that any commercial activity helps the growth of the economy of a sector, including informal activities (Wiley, 1994). 
This leads to the research question of this study: does the increase in the number of informal traders influence the reduction of formal sales of perishable goods within squares and markets of the city of Ambato, Ecuador? From this question arises the objective: to identify how the presence of informal traders has affected legitimate sales in the squares and markets of the city of Ambato.

\section{METHODOLOGY}

The research process is part of the empirical method, with a focus on the analysis of quantitative and qualitative data, measuring economic figures and socioeconomic factors (Hernández, 2000).

A total of 2040 types of perishable products sold to squares and markets in the city of Ambato (according to the information from the GAD of the municipality of Ambato). A random sample of 326 traders was chosen to participate in a survey. With a population of $99 \%$ female traders, sampling was carried out proportional to the population number, leading to a sample of 6 men and 320 women. This ratio agrees with statistical data from INEC (INEC, national Survey on employment, unemployment and underemployment, 2018), which suggests most income of this type is made by women.

The use of the questionnaire as a tool for collecting information was paramount, it allowed contact with the object of study (Castro, 2000). A survey can be defined as a primary technique of obtaining information on the basis of an objective, coherent and well-articulated set of questions. This technique ensures that the information provided by a sample can be analyzed by quantitative methods, and the results extrapolated (with certain errors and trusts) to a population (Grande \& Abascal, 2005). In this study, this approach allows the discovery of different situations around informal trade, such as the existence of municipal public ordinances for its regulation. The information gathering instruments were administered to the sample of traders in the markets by a student of business administration, during the hours of work of the formal traders (from 9 am to $4 \mathrm{pm}$ )

The information collected was analyzed using IBM SPSS Statistics 23. Descriptive statistics allowed determination of the main characteristics of certain phenomena, like identification of the principal reason for the reduction of sales in relation to the previous year. The Mann-Whitney $U$ was used to validate the hypotheses applied in this study because it allows analysis of non-parametric variables with relative ease and accuracy.

\section{RESULTS}

The results are summarized in three subsections: identification of the principal reason for the increase in informal traders, the influence of informal trade on formal traders, and evaluation of alternative solutions to improve the income of formal traders.

TABLE 1

REASONS FOR THE INCREASE IN INFORMAL TRADE

\begin{tabular}{|l|c|c|c|c|}
\hline What do you think is the reason for the increase in informal traders in the city of Ambato? \\
\hline & Frequency & Percentage & $\begin{array}{c}\text { Valid } \\
\text { percentage }\end{array}$ & $\begin{array}{c}\text { Cumulative } \\
\text { percentage }\end{array}$ \\
\hline $\begin{array}{l}\text { Dissatisfaction with the influx of buyers to } \\
\text { the sales stalls }\end{array}$ & 80 & 24.5 & 24.5 & 24.5 \\
\hline Lack of job opportunities & 114 & 35.0 & 35.0 & 59.5 \\
\hline Economic crisis & 132 & 40.5 & 40.5 & 100.0 \\
\hline Total & 326 & 100.0 & 100.0 & \\
\hline
\end{tabular}

Source: Applied Encueta 
In the sample of 326 respondents, the gender distinction of respondents is not relevant. A total of $24.5 \%$ of respondents indicate that informal traders formerly worked in some market in the city of Ambato, but due to a lack of buyers, decided to become informal traders. A large portion, 35\%, declare that a lack of job opportunities has directly influenced unemployed people to undertake informal trade, and $40.5 \%$ attribute the increase in informal trade to the current economic crisis. We conclude that informal trade has not increased based on a single factor, but on a number of factors that, combined, drive people without employment or with inadequate employment to seek different forms of income. It may be noted that the alternatives above could be encompassed in some way to the possessor factor of $40.5 \%$, being that, because of this, the situations presented were produced.

\section{TABLE 2 \\ PERCEIVED INFLUENCE OF INFORMAL TRADE}

\begin{tabular}{|l|c|c|c|c|}
\hline How does the presence of informal traders affect the city of Ambato? \\
\hline & & & & Cumulative \\
& Frequency & Percentage & Valid percentage & percentage \\
\hline Price of the products & 69 & 21.2 & 21.2 & 21.2 \\
Fewer buyers & 93 & 28.5 & 28.5 & 49.7 \\
Care of public spaces & 115 & 35.3 & 35.3 & 85.0 \\
Increase in crime & 49 & 15.0 & 15.0 & 100.0 \\
Total & 326 & 100.0 & 100.0 & \\
\hline
\end{tabular}

Source: Applied Encueta

According to respondents, informal trade affects traders in the supply markets in multiple ways. A total of $15 \%$ indicated that the presence of informal trade directly or indirectly influences an increase in delinquency, because the markets are meeting places for many people-buyers, informal sellers, and others - and with the increased number of people present, delinquency develops with greater ease. The role of informal traders in depressing prices is mentioned by $21.2 \%$, while $28.5 \%$ say that informal traders are the major reason buyers do not enter the markets. Respondents report that informal vendors offer convenience, low prices, and sometimes good customer service to buyers. Thus, informal traders represent significant competition for market vendors, and 35.3\% attribute damage to public places to informal traders. Many (49.7\%) respondents report that informal trade affects formal vendors directly, by a combination of depressing prices and reducing the number of buyers entering the market.

\section{TABLE 3 \\ IMPROVING THE NUMBER OF BUYERS ENTERING THE MARKET}

\begin{tabular}{|l|c|c|c|c|}
\hline How would you consider improving the influx of people to the market to which you belong? \\
\hline & Frequency & Percentage & Valid percentage & $\begin{array}{c}\text { Cumulative } \\
\text { percentage }\end{array}$ \\
\hline & 92 & 28.2 & 28.2 & 28.2 \\
$\begin{array}{l}\text { Creating a bus stop } \\
\text { Planning advertising and } \\
\text { promotions }\end{array}$ & 147 & 45.1 & 45.1 & 73.3 \\
$\begin{array}{l}\text { Implementation of chats } \\
\text { about customer service }\end{array}$ & 87 & 26.7 & 26.7 & 100.0 \\
$\quad$ Total & 326 & 100.0 & 100.0 & \\
\hline
\end{tabular}

Source: Applied Encueta 
The preferred factors for increasing the sales income of formal traders are increasing the traffic of buyers to markets and strategies for increasing sales. These two variables are related; it is necessary to attend to these two requirements to achieve the objective. An alternative solution chosen by $45.1 \%$ of respondents is the creation of an advertising and promotion plan, while $50.9 \%$ indicated that excellence in customer service would be a relevant factor driving buyers to choose to buy in the formal market.

TABLE 4

FACTORS LEADING TO INCREASED SALES

\begin{tabular}{|l|l|l|l|l|}
\hline What do you think is necessary to increase the sales of the job? \\
\hline & Frequency & Percentage & Valid percentage & $\begin{array}{l}\text { Cumulative } \\
\text { percentage }\end{array}$ \\
\hline $\begin{array}{l}\text { Give more discounts on } \\
\text { products }\end{array}$ & 68 & 20.9 & 20.9 & 20.9 \\
$\begin{array}{l}\text { Provide better customer } \\
\text { service }\end{array}$ & 166 & 50.9 & 50.9 & 71.8 \\
$\begin{array}{l}\text { Relocate informal traders } \\
\text { Total }\end{array}$ & 92 & 28.2 & 28.2 & 100.0 \\
\hline
\end{tabular}

Source: Applied Encueta

\section{DISCUSSION AND CONCLUSIONS}

The increase in informal trade is obvious in indicators published by the INEC and survey data from the present study. In recent years, different social, political and economic situations have drastically influenced decisions taken by society. Informal trading is one of the main consequences of poor management and decision-making in the public and private sectors.

There is a high unemployment rate (CITATION), and it appears one of the major causes of informal trade is a lack of employment opportunities. The unemployment rate in the city of Ambato is the highest in the country, at $6.4 \%$. Traders there see the results of this problem every day. Although unemployment is widely attributed to global factors, such as the current economic crisis, informal trade is also a major factor. Survey respondents (44.2\%) report that informal trade is one such factor. The degree of impact of informal trade on the "price" factor is $21 \%$. Because informal traders do not pay taxes, they can undercut the prices of formal traders, creating a huge price difference in relation to the prices of the same products in formal market stalls.

The presented solutions do not seem to be novel to the formal traders. They have already considered what measures are necessary to improve the market to which they belong. The consensus appears to be that application of a publicity plan will most improve sales, especially if combined with a modification of bus routes to increase traffic within the formal markets.

It appears the increase in informal trade in the city of Ambato has directly affected the decline in sales revenues of formal market traders. Law enforcement agencies have shown little interest in this growing problem. In addition to uncertainty about the omission by these institutions of certain public ordinances established in favor of formal traders, and for the restriction of informal activities.

Informal trade affects the economy of the province. Members of this labor force do not have labor guarantees and access to social security. However, casual traders do not want to stop work, because they perceive it is easier or more profitable to operate without submitting to regulation. 


\section{REFERENCES}

Correa, R. (2013, November 20). Presidencis, Republic of Ecuador. Retrieved from http://www.presidencia.gob.ec

Esquivel, G., \& Muñóz, M. (2007). Macroeconomics: Latin American version.Mexico: Pearson education.

Grande, I., \& Abascal, E. (2005). Survey analysis.Madrid: ESIC.

Hernández, E. (2000). Productivity and labor market in Mexico.Mexico: Plaza and Valdés.

Holzer, H. (1997, June). Informal Job Search and Black Youth Unemployment. The American Economic Review, 77(3), 446-452.

Inec. (2014). Methodology for the measurement of employment in Ecuador.Ecuador: Ecuador in figures.

Inec. (2018, March). National Survey of employment, unemployment and underemployment. Retrieved from http://www.ecuadorencifras.gob.ec/empleo-marzo-2018/

Jany Castro, J. (2000). Invetigación Integral de mercadoS: A focus for THE 21 st century.Mexico: Mc Graw Hill.

Jensen, L., Cornwell, G., \& Findeis, J. (2010, February 3). Informal Work in Nonmetropolitan Pennsylvania. Rural Sociology, 60(1), 91-107.

Leaders, R. (2015). Labor informality, a condition rooted in Ecuador. Leaders, 3.

Lundval, B.-ä., \& Johnson, B. (2006, May 26). The Learning Economy. Journal of Industry Studies, 1(2), 23-42.

Mankiw, G. (2009). Principles of Economics(Fourth ed.). Madrid, Spain: Auditorium.

Mingione, E. (1995, April). European Urban and Regional Studies. Labour Market Segmentation and Informal Work in Southern Europe, 2(2), 121-143. Obtenido de Labour Market Segmentation and Informal Work in Southern Europe.

Ministry of Coordination of Production, E. Y. (2011). Agendas FOR TERRITORIAL PRODUCTIVE transformation: Tungurahua.Ambato: Ministry of Coordination of Production, employment and competitiveness.

Minsky, H. (2013). Stabilizing an unstable economy. New York: Mc Graw Hill.

OECD. (2008). Manual on the measurement of the unobserved economy. Peru: Andean Community.

O. I.T. (2002). Decent work and the informal economy.Gin.

Pahl, R. (2009, October 14). Some remarks on informal work, social polarization and the social structure. (J. Editors, Ed.) International Journal of Urban and Regional Research, 12(2), 247-267.

Pelfren, E., \& Vlerick, P. (2010, December 16). Perceptions of job insecurity and the impact of world market competition as health risks: Results from Belstress. Journal of Occupational and Organizational Psychology, 76(4), 411-425.

Rivadeneira, A. (2015, March). INEC.Retrieved from Labor indicators: Www.ecuadorencifras.gob.ec Scott, A. (2009, October 14). Flexible production systems and regional development: the rise of new industrial spaces in North America and western Europe. (J. Editors, Ed.) International Journal of Urban and Regional Research, 12(2), 171-186.

Sinha, A., \& Kanbur, R. (2012). Introduction: Informality-Concepts, Facts and Models. Margin: The Journal of Applied Economic Research, 6, 91-102.

Torres, A. (2015). Spain 2015: social situation.Madrid: Treceocho edicion S.L.

United, N. (2006). Least developed Countries Report of 2006. Geneva: UNCTAD secretariat.

Vera, D. (2012). Population projections.Ecuador: INEC.

Wiley, J. (1994). Location and space-economy. Massachusetts: Massachusetts Institute of Technology. 